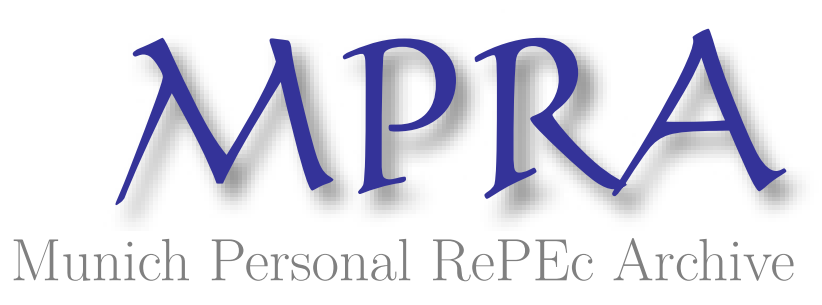

\title{
Trade Liberalization and Adjustment in Argentina
}

Londero, Elio

2003

Online at https://mpra.ub.uni-muenchen.de/85364/

MPRA Paper No. 85364, posted 25 Mar 2018 07:18 UTC 


\title{
TRADE LIBERALIZATION AND ADJUSTMENT IN ARGENTINA
}

Elio Londero *

April, 2003

\begin{abstract}
This paper looks at trade liberalization attempts in Argentina since 1970 with particular attention to the 1991-98 period, estimates the size of the adjustments required by the changes in the trade regimes, and looks at the degree of adjustment attained as manifested by the real effective exchange rate.
\end{abstract}

\section{J.E.L. Classification: F13, F14, F41}

Keywords: Trade, trade liberalization, adjustment, real exchange rate, Argentina

* Inter-American Development Bank. Opinions expressed in this paper are those of the author and are not intended to represent views of the Bank. Comments by Florencio Ballestero, Lutz Kilian, Antonio Spilimbergo, Simón Teitel and two anonymous referees are gratefully acknowledged. The author remains solely responsible for the results. This is an Accepted Manuscript of an article published by Taylor \& Francis in The Journal of International Trade and Economic Development on 17 May 2010, available online: https://doi.org/10.1080/09638190110073796. 


\title{
TRADE LIBERALIZATION AND
}

\section{ADJUSTMENT IN ARGENTINA}

\author{
Elio Londero ${ }^{1}$
}

\section{INTRODUCTION}

Trade liberalization occupied a central role in the policy reforms conducted in Latin America during the late eighties and early nineties. After a failed attempt in the late seventies, in1991 Argentina attempted one of the deepest trade liberalizations in the region as evidenced by the increase in the share of imports in GDP. A comparison of the percentage changes in average import coefficients between the 1995-98 and the 1975-78 periods shows Argentina with the greatest increase (253\%), followed by Mexico (159\%) and Colombia (108\%). ${ }^{2}$ A distinct feature of the Argentinean experience was the attempt to effecting such resource reallocation with the simultaneous liberalization of the capital account and the implementation of an antinflationary program based on a fixed exchange rate (Cavallo and Mondino, 1995).

In order to succeed, trade liberalization measures require a significant reallocation of resources between the production of traded (T) and nontraded (NT) goods. To be effected, such reallocation of resources generally requires a real depreciation of the domestic currency in order to increase the profitability of producing T goods relative to that of producing NT goods. The ensuing change in the sectoral composition of investment would lead to a higher share of imports and exports in GDP. Such is the importance attributed to attaining a real depreciation, that some authors have discouraged the simultaneous pursuit of other policies that could prevent it from happening. For example, it has been suggested to delay the opening of the capital account (Edwards, 1984, and references therein; Corden, 1987) to prevent capital inflows from appreciating the domestic currency, and to refrain from simultaneously implementing stabilization and trade liberalization programs to avoid the two conflicting roles that would be required from the exchange rate: nominal anchor and main instrument to reallocate resources (Corden, 1987, 1993; Edwards, 1991; Londero, 1997).

\footnotetext{
1. Inter-American Development Bank. Opinions expressed in this paper are those of the author and are not intended to represent views of the Bank. Comments by Florencio Ballestero, Lutz Kilian, Antonio Spilimbergo, Simón Teitel and two anonymous referees are gratefully acknowledged. The author remains solely responsible for the results.

2. Simple average of the four import coefficients, that is, $\Sigma_{t} m_{t} / 4$ where $m_{t}$ is the import coefficient in year $t$.
} 
This paper looks at Argentina's attempt at attaining a significant reallocation of resources between NT and T activities. It does not intend to review all policies implemented during the period, but rather focuses in: a) the size of the adjustment required as measured by the reduction in net exports attributable to the change in the trade regime; and $b$ ) the degree of success in attaining the required real depreciation. Such success is measured by the real depreciation attained in comparison with target values reflecting different levels of adjustment.

\section{ADJUSTMENT}

The relative price implications of liberalizing trade with a fixed exchange rate are well known (Harberger, 1985, 1986; Londero, 1997) and will not be repeated here. Suffice it to say that attaining a real depreciation would require reductions in the nominal prices of NT goods, and it would be thus complicated by any downwards inflexibility of these prices. It is conceivable, although unlikely, that lower prices of imported inputs, substitution of imported for nontraded inputs, and increased productivity could make the reduction in NT prices unnecessary (Corden, 1993). However, unless the process is accompanied by extraordinary increases in productivity in the production of traded goods relative to the production of nontraded goods, a reduction in nominal wages would be required (Londero, 1997).

A reduction in nominal wages is a necessary, but not a sufficient condition for a successful reallocation of resources. Lower nominal wages increase the profitability of investing in both $\mathrm{T}$ and NT goods, while the real depreciation should reflect a change in relative profitabilities. Adjustmentconducive macro policies should also be pursued in order to reduce the demand for NT goods, generating excess capacity in the NT industries and thus reducing the profitability of investing in such industries. A reduction in absorption through increasing the fiscal balance (reducing the deficit) not only would reduce the demand for NT goods, but it would also reduce the domestic demand for both imported and exported goods, thus contributing to reducing the real depreciation required to reach external short-term equilibrium. Improving the fiscal balance would keep real interest rates low, helping to increase the overall profitability of investment and making domestic financial markets less attractive to speculative capital inflows, thus reducing currency appreciation and future instability. By reducing the demand for labor (that is, at the cost of unemployment), the policy 
would also contribute to reducing real wages, and accompanied by competition, would eventually lead to the reduction in the prices of NT goods relative to those of T goods. By keeping interest rates and the demand for NT goods down, the policy would help signal the long-run relative profitability of investing in $\mathrm{T}$ goods, thus attracting the type of investment (including foreign investment) expected to contribute to adjustment. There would be a faster resumption of investment that responds to the new long-run relative prices, thus reducing future losses resulting from investments based on relative prices that will not prevail.

With the change in relative profitabilities the economy has complied with one necessary condition for the reallocation of resources. If investment in the production of T goods increases with price incentives, the economy would slowly increase employment in T industries, thus starting the process of reallocating labor from NT industries in the "without liberalization" situation to T industries in the liberalized situation. The size of the initial real depreciation may have to be large, it may have to exceed the new "equilibrium" real exchange rate in order to compensate for the additional risk of trying to penetrate international markets, and it may have to last a long period of time to allow the resource reallocation to take place. Only then, may the currency start appreciating towards its equilibrium level.

While the economics are clear, so are the politics. There are incentives for politicians to delay adjustment if they can get away with financing expansionary policies in order to maintain or increase employment in NT sectors. Borrowing in the international market would allow increasing the consumption of foreign goods, while passing the costs of adjustment to future generations (who do not vote now) and the political burden to future governments. Expansionary fiscal policies, however, have obvious drawbacks and clear limits. They reduce the incentives for the resource reallocation required by the change in trade policy, result in higher and persistent unemployment in import competing industries, and increase the probability of default when eventually lenders become increasingly concerned about repayment, leaving the country with a larger foreign debt and unable to generate in the short run the exports to repay it. ${ }^{3}$ Conversely, a policy that favors real depreciation carries a greater economic cost to the present generation (the one supporting the trade liberalization)

3. Also, there may be long-run development effects associated to prolonged overvaluations of the domestic currency. See Londero (1997). 
and a heavier political burden for the present government.

In addition to trade liberalization, other contemporaneous policy reforms contributed to another external shock. The liberalization of the capital account and of the financial system, together with a "perception" of no currency risk due to the currency board, helped amplify in Argentina the effects of the overall increase in capital inflows to Latin America (Calvo et al. 1993). While trade liberalization required a real depreciation to reallocate resources in the long run, temporary capital inflows forced, ceteris paribus, a real appreciation to restore domestic balance by switching expenditures to T goods (Salter, 1959; Corden, 1990). In terms of policy options, increasing protection and introducing capital controls were ruled out by the ideological commitment to external liberalization (although some minor increases in protection did take place). Thus the government restricted to one its options for reducing absorption: increasing the fiscal balance in order to curb the demand for NT goods and reduce interest rates to slow down capital inflows. The magnitude of the shocks would have required significant fiscal surpluses. Instead, the government did exactly the opposite. It chose to postpone the reduction in the profits of the NT sectors, and the ensuing increase in unemployment, by following expansionary fiscal policies financed by the privatization of assets and by borrowing. Such process was facilitated by capital inflows and the liberalization of the financial system. Paraphrasing Swan (1968), while claims were made that capital inflows sprang from "the magnitude of investment opportunities", the situation reflected more an international cycle and "a spendthrift disposition of the body politic". As the government persisted in transferring the cost of the adjustment to future governments and generations via additional foreign debt, resource reallocation from NT to T activities became more difficult due to insufficient price incentives while external debt mounted.

Debt financing of foreign exchange deficits originated in trade liberalization policies has sometimes been advocated for covering temporary gaps, which would be eventually closed when the full effect of policies takes place, or for attaining a better intertemporal distribution of costs and benefits. On the first count, by preventing the required real depreciation, debt financing is not covering temporary gaps, but hiding part of the inevitable cost and extending the period over which costs such as unemployment are going to be paid. As for the intertemporal distribution, it is true that the present generation would be paying costs with alleged associated benefits expected to accrue to 
the next generation. If a better distribution of those costs over time is desired, however, it is the trade liberalization policy itself that has to be implemented more gradually over time, thus avoiding the creation of foreign exchange deficits that exceed the adjustment capacity. By financing the deficits, the costs will eventually have to be paid, although at a higher price, and the alleged benefits would be delayed.

\section{STRATEGY}

The strategy consists simply of estimating a net exports equation to calculate the real exchange rate required to meet certain net export targets, and then compare that target real exchange rate with the prevailing one. The share of exports and imports in GDP is, ceteris paribus, expected to be stable over time as the economy grows along its trend path. Significant long-term changes in this share are expected from changes in commercial policies, relative productivity, and endowments -as, for example, when new natural resources are exploited. Short term fluctuations around this stable share could take place as a result of fluctuations in relative prices and activity levels. Therefore, the first step is to estimate a net-export equation as a function of relative prices and changes in commercial policies. Then the estimated equation is used to calculate the relative prices that would have resulted in certain balance of payments targets. Finally, the differences between actual and target relative prices are shown.

Assuming no major changes in relative productivities and endowments, the share of net exports in GDP is expected to depend on relative prices, deviations from trend GDP, and changes in commercial policy; that is,

$$
x_{t}=c+a_{0} \operatorname{rer}_{t-1}+a_{1} r e s d y_{t}+\sum_{i=2 \ldots k} a_{i} b_{i t}+a_{k+1} b_{h t} \operatorname{rer}_{t-1}+a_{k+2} b_{h t} r e s d y_{t}+\varepsilon_{t}
$$

where $x_{t}$ are the net exports of goods and non factor services in year $t$ as a percent of GDP, rer $_{t}$ is the real effective exchange rate expressed as domestic prices of traded goods relative to those of nontraded goods, resd $y_{t}$ is explained below, and the $b_{i t}$ are binary variables taking a unitary value for the years affected by significant trade policy changes and zero otherwise. The rer was lagged one period to account for the time lag between the production decision and the recording of the export 
(Londero, 2001). The resdy $y_{t}$ variable is the residual of regressing the ratio of actual GDP to HodrickPrescott trend GDP against $\operatorname{rer}_{t-1}, \ldots, \operatorname{rer}_{t-n}$ :

$$
G D P_{t} / \text { trend } G D P_{t}=b_{0}+\Sigma_{i} b_{i} \operatorname{rer}_{t-i},(i=1,2,3)
$$

Two to three lags were necessary to reduce serial correlation in the residuals so as to pass the Breusch-Godfrey LM-test with the number of lags suggested by an inspection of the corresponding correlograms. Finally, since trade liberalization may lead to changes in the responsiveness of trade to relative price and activity changes, equation [1] includes terms $b_{h t} r e r_{t-1}$ and $b_{h t} r e s d y_{t}$, where $h$ $\in(2,3, \ldots k)$ equals the subscript of the 1991 binary variable, since that is the most significant trade policy change. ${ }^{4}$ Changes in the price response of net exports associated to trade liberalization may have important implications for adjustment. For example, an increase in the price responsiveness would reduce the real depreciation required to adjust the foreign gap. At the same time, it would increase the gap resulting from any overvaluation of the domestic currency, leading to greater incremental indebtedness per unit of overvaluation. More debt per unit of overvaluation would lead to more interest payments, thus increasing the size of the inevitable adjustment.

These regressions share two limitations with most similar regressions. First, due to lack of data for the whole period they omit a variable for the trade incentives and disincentives, which did fluctuate during the pre-trade liberalization period (see, inter alia, Londero, Remes and Teitel, 1998, and Londero, 2001). Second, net export performance is also expected to reflect relative productivity changes in $\mathrm{T}$ sectors vis a vis competitors over time. For example, an increase in the productivity of import-competing sectors relative to the rest of the world would reduce the demand for imports and result in an appreciation of the equilibrium rer. With trade liberalization, increases in relative productivity are normally expected due to increased competition, and these productivity increases should have a positive effect on net exports (Corden, 1993; Londero, 1997). Relative productivity increases in the production of NT goods affect net exports if they translate into reductions in the prices of NT goods, and therefore they should be captured via the rer. Relative productivity

4. Note that the price or the activity coefficients would be $a$ for the years in which $b_{h t}=0$, and $a+\alpha_{h} b_{h t}$ when $b_{h t}=1$. 
increases in the production of $\mathrm{T}$ goods, however, affect net exports directly by increasing the profitability of traded sectors, and are thus expected to lead to increases in net exports.

While there may have been changes in relative productivity levels attributable to the reductions in protection and associated policies, no reliable data on productivity exists at sectoral or subsectoral levels, let alone for $\mathrm{T}$ industries. Therefore, these effects could not be included. If relative productivity increases in the production of $\mathrm{T}$ goods would take place immediately after trade liberalization, their effects would be absorbed by the corresponding binary variables, thus leading to an underestimation of the effects of the pure policy change. Alternatively, if these productivity increases took place over time, they are more likely to show up in the residuals.

The expected signs of the coefficients were positive for the price variable $\left(a_{0}>0\right)$ and negative for the activity variable $\left(a_{1}<0\right)$. In Argentina, a significant reduction in protection started in 1977 (Kosacoff, 1993), to return to a more protectionist regime in 1982; therefore, a negative coefficient is expected for the coefficient of the corresponding binary variable. The binary variable in fact covers the 1979-81 period, since the first two years affected primarily redundant protection. The second and deeper trade-liberalization attempt started in 1991 and continued throughout the period. Hence, the coefficient is expected to be negative and larger than the 1979-81 in absolute value. In 1991 Argentina entered the MERCOSUR trade agreement, which included an automatic linear reduction of tariffs concluded in 1994 (Bouzas, 2001). Binary variables for MERCOSUR were tried for years 1994 and 1995, since during the preceding years the multilateral liberalization dominated the performance of the economy and the initial MERCOSUR tariff reductions were relatively small. There is no a priori sign expected for this coefficient, since joining MERCOSUR would change Argentina's trade regime towards its MERCOSUR, partners as well as Argentina's partners trade regime towards Argentina. For example, Argentina's tariffs for Brazilian goods were reduced, as were Brazilian tariffs for Argentina's goods. The values of the coefficients for the binary variables may be interpreted as the changes in net exports (as a percent of GDP) resulting from the changes in trade policy for given values of rer $_{t-1}$ and resdy.

Given the extent of quantitative restrictions that were in place in Argentina, it may be argued that trade liberalization would have increased the price responsiveness of net exports (a positive coefficient for the $b_{h t} r e r_{t-1}$ variable). Additionally, trade liberalization increased the availability of 
substitutes for nontraded goods, thus increasing the price responsiveness of the demand for imports. On the other hand, in natural resource rich countries, the reduction or elimination of protection and export incentives leads to a reduction in the share of labor-intensive manufactures in total exports and to an increase in the share of more rent intensive products. Since the former are expected to be more price responsive than the latter, trade liberalization may lead to a reduction in the price responsiveness of exports. As a result, the sign of the $b_{h t}$ rer $_{t-1}$ variable is a priori undetermined. As regards changes in activity levels, an increase in import and export coefficients would lead to a greater reduction in net exports per unit increase in activity levels, therefore a negative coefficient is expected for the $b_{h t} r e s d y_{t}$ variable.

\section{DATA}

The Economic and Social Database of the Inter-American Development Bank and the International Monetary Fund are the main sources of the data used (see Appendix 1). Net exports and GDP are in local currency at 1990 prices. Observations for 1975-76 were dropped because data on exports is deemed to be inaccurate (CEPAL, 1986).

The primary constraint for selecting the study period was the availability of rer data (Figure 1). IMF series starts in 1980, and when this study started data was available only up to 1998. Additional rer data from 1970 was obtained from World Bank (1989).

Testing for unit roots in the data poses significant problems. First, unit root tests should be conducted taking into account

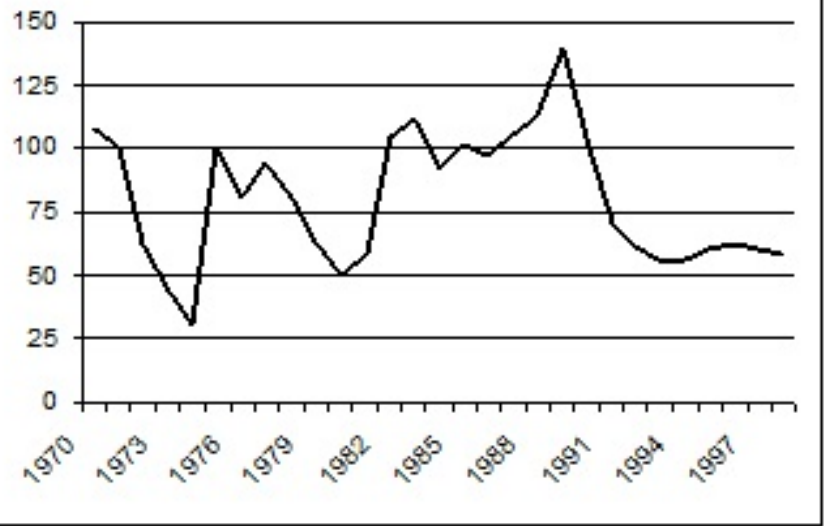

Figure1. Real effective exchange rate structural changes generated by the changes in commercial policy (Perron, 1990). For example, the equilibrium rer might vary with such changes, and thus rer series should not be expected to show mean reversion. Also, the liberalization of the capital account may allow for higher deficits to be financed by capital inflows, and these effects may be persistent during the period analyzed, since adjustment to the more liberal trade regime has not been completed. Once the existence of structural 
changes and persistent effects is recognized, the question is whether the available series allow for the testing. First, the length of the series is insufficient for splitting them at the breaks for testing purposes. Second, the low power of unit root tests is reduced by the inclusion of structural breaks. As a result, the small number of observations would have made it very difficult to discriminate a unit root from a stationary series with a smaller but relatively high root, rendering a non rejection of the unit root hypothesis of very little practical value. Therefore, testing for unit roots was not attempted.

\section{REGRESSION RESULTS}

Regressions were performed using equation [1] with the net export coefficients measured as a percent of GDP, the rer index representing the relative price of T to NT goods on a $1990=100$ basis, and resdy measured in percentages. Therefore, the rer coefficients indicate the change in the net export coefficient (percentage points of GDP) per unit of change in the rer index. Considering that the four observations preceding 1980 correspond to a different estimation of the rer, that the 1979-81 years are covered by the binary variable, and that 1977-78 are transition years in the first trade liberalization attempt, a second set of regressions covering only the 1982-98 was also estimated. Finally, equations for the 1970-98 period (excluding 1975-76) are also presented.

Only the equations omitting the $b_{91}$ rer $_{t-1}$ variable are presented, since coefficients for this variable showed very low statistical significance in all equations. The variable is collinear with the 1991 binary variable due to the low variability of the rer after 1991, leading to clearly incorrect estimates of the 1991 binary variable. It should not be inferred from this result that the price response of net exports was not affected by trade liberalization, but rather that the available information was insufficient to provide evidence on whether it actually took place.

The results, presented in Table 1, show that the $t$-statistics associated to all coefficients and the adjusted coefficients of determination $\left(\overline{\mathrm{R}}^{2}\right)$ are high. All equations pass a Breusch-Godfrey LM test for serial correlation in the residuals and a RESET specification error test. The White test for heteroskedasticity shows that the first regression may be affected by it, therefore the two $t$-statistics reported for each coefficient were calculated using White and Newey-West methods.

All coefficients with a priori expectations carry the expected signs and estimated values of the price response of net exports are remarkably consistent among equations. The size of the 
coefficients show the importance of attaining a significant $r e r$ depreciation for adjustment. The price response of net exports is relatively low. A ten-point real depreciation at the average rer would increase net export shares by less than a half percentage point. This low response of net exports to relative prices may be due to the importance of rent intensive products (Londero, Remes and Teitel, 1998; Londero 2001), since producers absorb price changes via changes in rents. The explosive increase of Argentina's import coefficient after 1991 seems to be explained partially by trade

Table 1. Net exports of goods and nonfactor services as a percent of GDP: OLS estimations of equation [1].

\begin{tabular}{|l|c|c|c|}
\hline Equation [1] & $1977-98$ & $1982-98$ & $1970-74,1977-98$ \\
\hline$c$ & -2.29 & -1.8 & -2.53 \\
& $(2.9,3.1)$ & $(3.1)$ & $(2.9)$ \\
\hline rer ${ }_{t-1}$ & 0.046 & 0.041 & $(5.2)$ \\
\hline resdy & $(6.0,6.2)$ & $(7.3)$ & -0.18 \\
& -0.17 & -0.21 & $(3.2)$ \\
\hline$b_{91}$ resdy & $(4.1,3.9)$ & $(7.5)$ & -0.48 \\
& -0.49 & -0.45 & $(3.5)$ \\
\hline$b_{79-81}$ & $(11.2,9.8)$ & $(7.3)$ & -2.33 \\
& -2.60 & & $(3.7)$ \\
\hline$b_{91}$ & $(2.7,4.2)$ & & -3.42 \\
& -3.66 & -3.42 & $(6.5)$ \\
\hline$b_{95}$ & $(12.4,16.3)$ & $(12.3)$ & -1.02 \\
& -1.01 & -1.68 & $(1.6)$ \\
\hline \hline $2 \bar{R}$ & $(5.5,7.0)$ & $(5.7)$ & 0.91 \\
\hline Observ. & 0.96 & 0.99 & 25 \\
\hline RESET & 22 & 17 & 0.91 \\
\hline DW & 0.48 & 0.58 & n.a. \\
\hline BG & 2.39 & 2.66 & 0.79 \\
\hline White & $0.09(2)$ & $0.09(6)$ & 0.54 \\
\hline
\end{tabular}

* Absolute value of $t$ statistics between parentheses. For the 1977-98 period: (White, Newey-West). Number of observations after adjusting for endpoints. RESET test: $p$-value for the $F$-test for squares, cubes and fourth powers of the fitted values. DW: Durbin-Watson statistic. BG: lowest $p$-value from the Breusch-Godfrey LM test for serial correlation in the residuals; lags 1 to 6 were tried, lags for the reported value between parentheses. White heteroskedasticity test: $p$-values for White's test statistic $\left(\mathrm{N} \times \mathrm{R}^{2}\right)$. 
liberalization, and partially by the substantial overvaluation of the domestic currency (see below). ${ }^{5}$

The coefficients for the binary variables are sizable and robust to changes in the estimation period. As expected, the impact of the 1991 trade liberalization as measured by its impact on net exports is much larger (40 to 50 percent larger) than the 1979-81 liberalization. The 1995 MERCOSUR binary variable turns out to be negative and also sizable, but its size is not as robust to changes in the estimation period. A 1994 MERCOSUR binary variable yields economically and statistically equivalent results. There is no intention to suggest that these coefficients are precise estimates of the impact on net exports, but the results are statistically highly significant and consistent among equations. In particular, these results show the sizable reductions in net exports attributable to trade liberalization measures. The Argentinean economy was the subject of four significant self-inflicted trade shocks in a period of 15 years, and the estimated magnitudes of these effects are illustrative of the required adjustments. The failed stabilization cum trade liberalization program of 1979-81 and the traumatic return to a more protected economy in 1982 seem to have led to the 1991 stabilization cum trade liberalization program, the adjustment to which was made more difficult by the full implementation of regional trade liberalization in MERCOSUR.

Estimates of the net export response to changes in activity levels (resdy) are also remarkably consistent among equations, as is the increase in such response after trade liberalization ( $b_{91}$ resdy). Coefficients for resdy are sizable and statistically highly significant. Before the 1991 trade liberalization, an increase in resdy of one percent point of GDP would have reduced net-export shares by about a fifth of a percentage point. After 1991, the same increase in resdy would lead to a reduction larger than three fifths of a percentage point.

5. As noted by Díaz Alejandro (1965) and formalized by Jarvis (1974), increases in beef prices lead producers to increase the stocks and thus temporarily reduce supply, which would later on increase but not without a significant lag. Such behavior would result in a lagged response of cattle-based exports, once an important part of Argentina's exports, to price changes. An equation including two-, three- and four-lagged price variables was tried with disappointing results, except perhaps for one case: in the equation for the $1982-98$ period, results for the $3^{\text {rd }}$ lag are less disappointing, but statistically significant only at the $7.5 \%$ level. These results should not be construed as evidence against the hypothesis of longer lags for products like cattle-based exports, since these price effects would be very difficult to capture at the level of aggregation used in this study. They may rather be due to the decline in the share of cattle based exports. The results reported in Table 1 are robust to the inclusion of additional lags for the price variable. 


\section{NET EXPORT TARGETS AND REAL EXCHANGE RATE LEVELS}

The results of Table 1 in conjunction with the series in Figure 1 suggest that there may have been some significant exchange rate misalignment after trade liberalization. No attempt is made here to estimate an equilibrium real exchange rate, and therefore no precise judgement can be made regarding rer misalignment. ${ }^{6}$ Notwithstanding these limitations, the estimated net-export equations allow for the calculation of the real depreciations that would have been required to compensate for the reduction in net exports attributable to trade liberalization as estimated by the binary-variable coefficient. These estimates provide indicative results and allow for some tentative conclusions to be reached.

Equation [1] allows for the series of the rer that would have kept the fitted net export coefficient at different reference levels to be calculated. These reference levels will be calculated assuming that the economy performs along the trend GDP (resdy $=0)$ and including the changes in the trend values of main determinants of the balance of payments results, namely foreign debt and foreign direct investment, that result from financial and capital account liberalization. These reference-level rer may be calculated as those that satisfy

$$
\tilde{x}_{i t}=\hat{c}^{+} \hat{a}_{0} r \tilde{e} r_{i t-1}+\Sigma_{i} \hat{a}_{i} b_{i t} \quad(i \in[2,3, \ldots k])
$$

where $\tilde{x}_{i t}$ is the target net-export value $i$ in year $t, r \tilde{e} r_{i t-1}$ is the real effective exchange rate that would have attained that target, and $\hat{c}, \hat{a}_{0}$, and $\hat{a}_{i}$ are the estimated coefficients from Table1. It should be noted that equation [3] would provide the value of $r \tilde{e} r_{i t-1}$ for a given situation at the end of the preceding year. In other words, this simple approach cannot answer questions regarding intertemporal effects, such as those of a real depreciation in the preceding year that would have reduced the need of additional foreign debt, and consequently the amount of interest paid to foreigners in the following year.

Targets are defined following the balance of payments accounting identity (IMF, 1993), and expressed as a percent of GDP:

6. Edwards and Savastano (1999) provide a review of real exchange rate misalignment estimates. 


$$
\begin{aligned}
& x+i b+c t b+c a b+f a b=0 \\
& f a b \equiv d i b+p i b+o i b+c r
\end{aligned}
$$

where $i b$ is the income balance, $c t b$ is the current-transfers balance, $c a b$ is the capital account balance, $f a b$ is the financial account balance, $d i b$ is the direct investment balance, pib is the portfolio investment balance, $o i b$ is the other investment balance, and $c r$ is the change in reserves. ${ }^{7}$ Therefore,

$$
x+i b+c t b+c a b+d i b+p i b+o i b+c r=0
$$

All targets are calculated with respect to trend values and require no changes in reserves in that year $(c r=0)$. Therefore, net export target $i$ would be of the form

$$
\tilde{x}_{\mathrm{i} t}=-\left(i \bar{b}_{t}+c \bar{t} b_{t}+c \bar{a} b_{t}+d \bar{i} b_{t}+\Delta d_{i t}\right)
$$

where the dashes indicate Hodrick-Prescott trend values and $\Delta d_{i t}$ is the allowed change in debt as a share of GDP. ${ }^{8}$ Note that this formulation assimilates pib + oib to external debt while pib may include the net acquisition of equity securities by foreigners (IMF, 1993, par. 474).

Targets are initially calculated from balance of payments data and GDP in current US dollars (see Appendix 2). Therefore, before using equation [3] they must be expressed in the same (1990) prices used for estimating equation [1]. Net export shares in year $k$ at 1990 prices used to estimate equation [1] may be expressed as

$$
x_{k}=X_{k}\left(e_{90} / e_{k}\right)\left(P_{90}^{x} / P_{k}^{x}\right) /\left[Y_{k}\left(P_{90}^{y} / P_{k}^{y}\right)\right]
$$

where $X_{k}$ are net exports at current domestic prices in year $k, e_{k}$ is the exchange rate, $P_{t}^{x}$ are net export

7. For detailed definitions see IMF (1993).

8. Separate capital account data was not available for Argentina, but is shown to be negligible during the nineties in the International Financial Statistics of the International Monetary Fund. 
prices, $Y_{t}$ is GDP at current prices, and $P_{t}^{y}$ is the GDP deflator. The same export share may be expressed at year's $t$ prices by multiplying it by

$$
I_{t}=\left[\left(e_{t} / e_{90}\right)\left(P_{t}^{x} / P_{90}^{x}\right) /\left(P_{t}^{y} / P_{90}^{y}\right)\right]
$$

Note that the preceding expression is similar to the index of the real effective exchange rate calculated with respect to the GDP deflator. Therefore, $I_{t}$ may be approximated by correcting the index of the consumer price index $(C P I)$ based rer for the change in the GDP deflator

$$
I_{t}=\left[\left(e_{t} / e_{90}\right)\left(P_{t}^{x} / P_{90}^{x}\right) /\left(P_{t}^{y} / P_{90}^{y}\right)\right] \simeq \operatorname{rer}_{t}\left(C P I_{t} / C P I_{90}\right) /\left(P_{t}^{y} / P_{90}^{y}\right)
$$

Thus, targets at year's $t$ prices are expressed at 1990 prices by dividing them by $I_{t}$.

Net export targets should not be independent of the desired levels of indebtedness, and such levels should not exceed prudent limits. Two types of indicators are often used in the literature of debt sustainability limits: debt to GDP and debt to exports plus net remittances. In the case of Argentina, only debt to exports plus remittances ratios will be used, since the low export coefficients make them

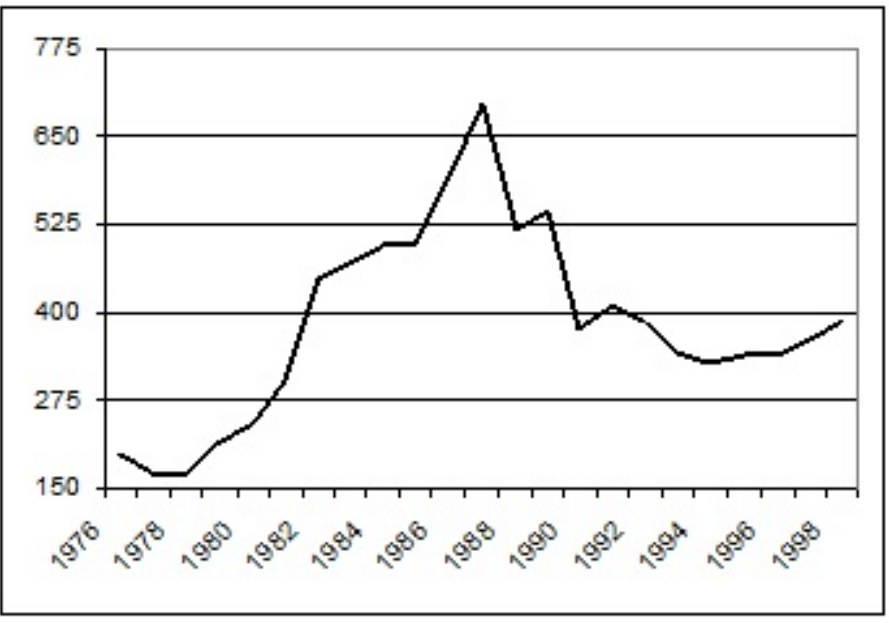

Figure 2. External debt to exports ratio, percent. dominant over those with respect to GDP. During the eighties, the debt to exports ratio exceeded the suggested limits (Figure 2) and despite a significant reduction in the early nineties, it remained high. Therefore, net export targets for Argentina should aim at reducing the debt to exports levels.

The first series of targets for net exports requires that in each year, changes in portfolio and other investments equal those necessary to compensate for the difference between trend and actual shares of GDP of the income, current transfer, capital account and direct investment balances. In other words, no additional debt would be contracted as long as these balances stayed at their trend 
levels $\left(\Delta d_{1 t}=0\right)$. Expressed at 1990 prices the first series of targets becomes

$$
\tilde{x}_{1 t}=-\left(\bar{i} \bar{b}_{t}+c \bar{t} b_{t}+c \bar{a} b_{t}+\bar{d} \bar{i} b_{t}\right) / I_{t}
$$

where the dashes indicate Hodrick-Prescott trend values. Note that as trend exports grow, this target implies a declining external debt to exports ratios over time.

The World Bank (2000) provides indicative boundaries for managing external debt using the present value of debt service to the average exports of goods and services plus remittances for the last three years. According to the World Bank, a country is said to be "severely indebted" if the ratio to exports plus remittances exceeds 220 percent, and it is said to be "moderately indebted" if the rate is higher than 132 percent (60 percent of the upper limit), but lower than 220 percent. ${ }^{9}$ Note that Argentina has exceeded the "severely indebted" threshold since the early eighties (Figure 2). A severely indebted country is one that would face a high risk of being unable to service its debt due to a shortage of foreign exchange (World Bank, 2000; Hjertholm, 1999). A clear definition of "moderately indebted" does not seem to have been provided. ${ }^{10}$

The difficulty with the present value measure for this analysis is that it is not possible to associate reductions in present value measures with reductions in the stock, since the present value may be reduced by means other than reducing the stock. For this reason, the less precise pre-1992 World Bank thresholds based on debt stock were used. ${ }^{11}$ According to these limits, a country would be severely indebted if its debt to exports-plus-remittances ratio would exceed 275 percent. A 60 percent of this limit (165 percent) is used by the World Bank to determine the lower bound for the "moderately indebted" classification.

Based on the preceding discussion, two additional series of targets are formulated. In the first one, a debt reduction is required when the debt to trend exports plus remittances ratio exceeds the

9. These indicators are not beyond dispute. Criticisms are based on the potential overestimation of the upper bound $(220 \%)$, the "one size fits all" approach, and the neglect of growth considerations. For a critical review see Hjertholm (1999).

10. But see Hjertholm (1999: 19).

11. See Hjertholm (1999). 
"severely indebted" threshold ( 275 percent). The associated yearly targets require that when the limit is exceeded, the country should reduce the difference between its ratio of actual debt to trend exports plus remittances and 2.75 in 10 percent. Therefore, the debt change required to comply with the second series of targets would be

$$
\begin{aligned}
& \Delta D_{t} /\left(\bar{X}_{t}+\bar{R}_{t}\right)=\left[2.75-D_{t} /\left(\bar{X}_{t}+\bar{R}_{t}\right)\right] / 10 \\
& \Delta D_{t}=\left[2.75\left(\bar{X}_{t}+\bar{R}_{t}\right)-D_{t}\right] / 10
\end{aligned}
$$

which expressed as a percentage of GDP is

$$
\left.\Delta d_{2 t}=100 \times\left[2.75\left(\bar{X}_{t}+\bar{R}_{t}\right)-D_{t}\right] / 10 Y_{t}\right]
$$

Therefore, the second series of targets is

$$
\tilde{x}_{2 t}=-\left(i \bar{b}_{t}+c \bar{t} b_{t}+c \bar{a} b_{t}+\overline{d i} b_{t}+\Delta d_{2 t}\right) / I_{t}
$$

In the third series of targets, a debt reduction is required when the debt to trend exports plus remittances ratio exceeds the midpoint between the lower limits for "moderately indebted" and "severely indebted". The associated targets require that when that midpoint (220 percent) is exceeded, the country should reduce the difference between its ratio of actual debt to trend exports plus remittances and the midpoint in 10 percent. Therefore, the debt change required to comply with the third series of targets, expressed as a share of GDP, is

$$
\left.\Delta d_{3 t}=\left[2.2\left(\bar{X}_{t}+\bar{R}_{t}\right)-D_{t}\right] / 10 Y_{t}\right]
$$

and the third series of targets is

$$
\tilde{x}_{3 t}=-\left(i \bar{b}_{t}+c \bar{t} b_{t}+c \bar{a} b_{t}+\overline{d i} b_{t}+\Delta d_{3 t}\right) / I_{t}
$$


Table 2. Net-export targets

\begin{tabular}{|l|l|l|l|}
\hline Year & $1 \tilde{x}$ & $2 \tilde{x}$ & $3 \tilde{x}$ \\
\hline 1977 & 0.85 & 0.85 & 0.85 \\
1978 & 1.64 & 1.64 & 1.64 \\
1979 & 3.11 & 3.11 & 3.72 \\
1980 & 4.43 & 5.23 & 5.99 \\
1981 & 4.79 & 6.62 & 7.31 \\
1982 & 3.60 & 5.49 & 5.95 \\
1983 & 4.07 & 6.15 & 6.64 \\
1984 & 5.08 & 7.78 & 8.37 \\
1985 & 4.45 & 6.85 & 7.37 \\
1986 & 4.14 & 6.36 & 6.86 \\
1987 & 3.57 & 5.82 & 6.27 \\
1988 & 3.36 & 5.35 & 5.82 \\
1989 & 2.39 & 4.07 & 4.45 \\
1990 & 2.53 & 4.04 & 4.52 \\
1991 & 2.44 & 4.03 & 4.61 \\
1992 & 1.96 & 3.34 & 3.95 \\
1993 & 1.39 & 2.12 & 2.72 \\
1994 & 0.92 & 1.79 & 2.39 \\
1995 & 0.50 & 2.02 & 2.59 \\
1996 & 0.19 & 1.80 & 2.37 \\
1997 & -0.09 & 1.92 & 2.52 \\
1998 & -0.35 & 1.78 & 2.40 \\
\hline
\end{tabular}

Sources: $\tilde{x}_{i}$ calculated from expressions [7], [8] and [9].

Table 3. Ratios of target to prevailing rer

\begin{tabular}{|l|l|l|l|l|l|l|l|c|c|}
\hline \multirow{2}{*}{ Year } & \multicolumn{3}{|c|}{$1970-741977-98$} & \multicolumn{2}{|c|}{$1977-98$} & \multicolumn{3}{|c|}{$1982-98$} \\
\cline { 2 - 9 } & $r_{1 t}$ & $r_{2 t}$ & $r_{3 t}$ & $r_{1 t}$ & $r_{2 t}$ & $r_{3 t}$ & $r_{1 t}$ & $r_{2 t}$ \\
\hline 1977 & 1.05 & 1.05 & 1.05 & 1.11 & 1.11 & 1.11 & & \\
1978 & 0.47 & 0.47 & 0.44 & 0.47 & 0.47 & 0.44 & & \\
1979 & 0.31 & 0.29 & 0.27 & 0.31 & 0.29 & 0.27 & & \\
1980 & 0.24 & 0.21 & 0.19 & 0.24 & 0.21 & 0.19 & & \\
1981 & 0.44 & 0.34 & 0.32 & 0.46 & 0.35 & 0.33 & & \\
1982 & 0.74 & 0.56 & 0.53 & 0.76 & 0.58 & 0.54 & 0.73 & 0.54 & 0.51 \\
1983 & 0.68 & 0.50 & 0.48 & 0.70 & 0.52 & 0.49 & 0.66 & 0.48 & 0.45 \\
1984 & 0.61 & 0.46 & 0.43 & 0.64 & 0.47 & 0.44 & 0.61 & 0.44 & 0.41 \\
1985 & 0.70 & 0.53 & 0.50 & 0.73 & 0.54 & 0.51 & 0.69 & 0.51 & 0.48 \\
1986 & 0.74 & 0.54 & 0.51 & 0.77 & 0.56 & 0.53 & 0.74 & 0.52 & 0.50 \\
1987 & 0.83 & 0.62 & 0.59 & 0.87 & 0.64 & 0.60 & 0.84 & 0.60 & 0.57 \\
1988 & 1.07 & 0.80 & 0.75 & 1.12 & 0.83 & 0.78 & 1.10 & 0.79 & 0.74 \\
1989 & 1.28 & 0.98 & 0.92 & 1.34 & 1.02 & 0.95 & 1.32 & 0.98 & 0.90 \\
1990 & 0.55 & 0.52 & 0.49 & 0.55 & 0.52 & 0.49 & 0.53 & 0.44 & 0.42 \\
1991 & 0.42 & 0.40 & 0.38 & 0.42 & 0.40 & 0.37 & 0.41 & 0.34 & 0.32 \\
1992 & 0.39 & 0.41 & 0.37 & 0.39 & 0.41 & 0.37 & 0.38 & 0.34 & 0.32 \\
1993 & 0.38 & 0.39 & 0.36 & 0.38 & 0.39 & 0.36 & 0.37 & 0.32 & 0.30 \\
1994 & 0.35 & 0.33 & 0.31 & 0.35 & 0.33 & 0.31 & 0.31 & 0.26 & 0.24 \\
1995 & 0.39 & 0.36 & 0.34 & 0.39 & 0.36 & 0.34 & 0.35 & 0.28 & 0.27 \\
1996 & 0.42 & 0.37 & 0.34 & 0.42 & 0.37 & 0.34 & 0.37 & 0.29 & 0.27 \\
1997 & 0.42 & 0.37 & 0.34 & 0.42 & 0.36 & 0.34 & 0.38 & 0.28 & 0.27 \\
\hline
\end{tabular}

Note: $r_{i t}=r e r_{i t} / r \tilde{e} r_{i t}$.

Source:rẽ $r_{i t}$ calculated with equation [10] using targets[7], [8] and [9]. 
Net export targets $\tilde{x}_{i t}$ as defined by equations [7], [8] and [9] are presented in Table 2. These targets were then used to estimate the rer that would meet them. The series for these target $r \tilde{e} r_{i t}$ were calculated from equation [3] as

$$
r \tilde{e} r_{i t}=\left(\tilde{x}_{i t}-c-\Sigma_{i>1} a_{i} b_{i t}\right) / a_{0}
$$

and reported as ratios of the prevailing to the target rer, that is $r_{i t}=r e r_{t} / r \tilde{e} r_{i t}$. These results are presented in Table 3. These estimates of $r \tilde{e} r_{i t}$ are year by year results, taking factor payments in each year, and thus the accumulated stocks of foreign capital and debt, as given. They do not show the effects in year $t$ of the changes in these stocks that would result from pursuing the target in year $t$ 1. Also note that: i) due to the lag in the rer in equation [1], ratios $r_{i t}$ compare the prevailing rer with the one that should have existed in order to reach the target the following year; and ii) as mentioned in section 3, the price response of net exports may have increased after trade liberalization and thus the rate of overvaluation may be overestimated.

The first important conclusion is that trade liberalization started and continued with a significant overvaluation of the domestic currency. The rate at which the peso was fixed to the US dollar in 1991 implied a rer significantly below that prevailing in the preceding years (see Figure 1). Such rate was established when adjustment to trade liberalization demanded a real depreciation. The overvaluation increased after 1991 due to inertial inflation. Further evidence of this initial overvaluation is provided in Figure 3. The monthly series of the rer shows the significant appreciation that took place since mid 1990 and the small real depreciation that took place in 1991, when the rate at which the peso was fixed was only able to attain a rer level below that prevailing in the late eighties. In short, the peso was fixed at an overvalued rate even when compared with

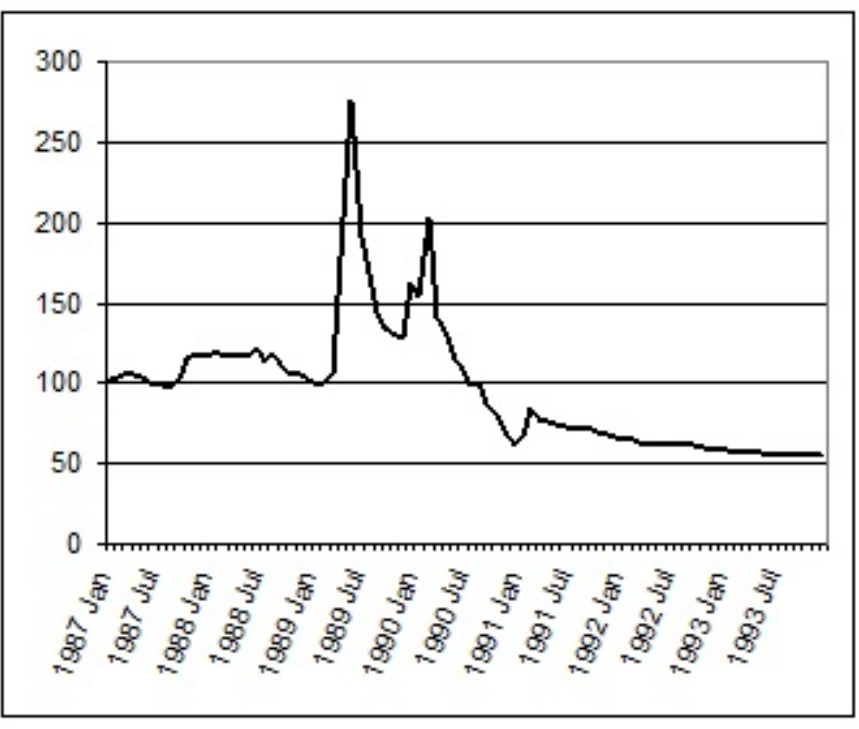

Figure 3. Monthly rer, 1987-93 
the pre-trade liberalization levels! Fixing the peso ignored trade liberalization, and the domestic currency remained significantly overvalued throughout the nineties (Table 3).

The preceding results are also reflected in the external debt to exports ratios (Figure 2). By 1991, when the trade regime was changed, the external debt was already high relative to exports. Then, in 1993-94 a debt renegotiation agreement and trade liberalization reduced debt relatively to exports. As time went by, it became increasingly difficult to finance fiscal deficits with the privatization of assets, and external indebtedness increased as adjustment was insufficient. Nevertheless, despite the fact that export targets were significantly lower during the nineties due to the increase in trend exports, the overvaluation of the domestic currency remained high because of the appreciation at the time of fixing the rate, inertial inflation and the effects of MERCOSUR.

\section{CONCLUSIONS}

This paper has shown that, as expected, Argentina's net export coefficient responds to relative prices, fluctuations in activity levels around the trend, and changes in commercial policy. The estimated coefficients reveal that these variables explain a substantial part of the variation in net export coefficients. More interesting, the estimated coefficient for the fluctuations in activity levels experienced roughly a three fold increase after trade liberalization; in other words, net exports seem to have become significantly more responsive to activity fluctuations. An attempt to determine whether the price response had also been affected by trade liberalization was unsuccessful due to the limited variability of the real effective exchange rate after trade liberalization.

Starting in 1977-78, the Argentinean economy was subjected to four significant trade policy shocks, each one of them requiring a sizable adjustment. The results show that there was insufficient adjustment to the two liberalization attempts and to MERCOSUR, as evidenced by the overvaluation of the rer with respect to reasonable target levels. The two major trade liberalization attempts (197981 and 1991-) required significant levels of adjustment as measured by the estimated changes in net exports attributable to these policy changes. These estimated changes varied between 2.3 and 2.6 percentage points of GDP for the first attempt and between 3.4 and 3.7 for the second one. These figures illustrate the magnitude of the resource reallocations demanded by these policy changes. Given the estimated price response of net exports, these resource reallocations asked for significant 
real depreciations of the domestic currency. Nevertheless, real appreciations followed each of the two main trade liberalization attempts.

These estimates suggest that Argentina's participation in MERCOSUR required an additional adjustment equivalent to increasing net exports in the order of one to 1.7 percentage points of GDP. However, the estimated coefficient is less robust to changes in the estimation period, and in one of the equations its statistical significance is substantially lower than that of other coefficients.

A significant number of years elapsed since the liberalization of the trade regime in 1991 without relative prices adjusting to the new situation. This delay has had important consequences for the Argentinean economy. There has been a greater than required destruction of productive capacity in import competing sectors, and less investment than required in the production of traded goods. As a result, the resumption of growth at the new equilibrium relative prices has been delayed and the period of high unemployment has been prolonged.

The persistency of an overvalued domestic currency was possible due to substantial external capital inflows, primarily in the form of debt. The ensuing increases in indebtedness should have been a source of concern as indicated by the debt to exports ratio. As time went by, the servicing of such debt became more and more difficult the longer it took to (re)allocate resources to the production of traded goods and to resume growth. The results are now (June 2002) history. Under the present circumstances a sustainable level of debt will have to be achieved, and adjustment would have to take into account new trend values for capital inflows.

\section{Appendix 1. Data sources}

Exports and imports of goods and non factor services, as well as GDP, all in local currency at constant prices, from national accounts data of the Economic and Social Database (ESDB) of the Inter-American Development Bank. Real effective exchange rates from International Monetary Fund estimates for the 1980-98 period, and from World Bank(1989) for 1970-80; the 1980-98 series is extended to 1970 by applying the rate of change of the World Bank series. Direct investment balance, income balance and current transfers balance data, all in current US dollars, from balance of payments data from ESDB. GDP in current US dollars, also from ESDB. GDP deflator, yearly CPI, and debt to export ratios from World Bank (2000). CPI monthly series from INDEC. 
Appendix 2. Current transfers, direct investment and income balances (current prices)

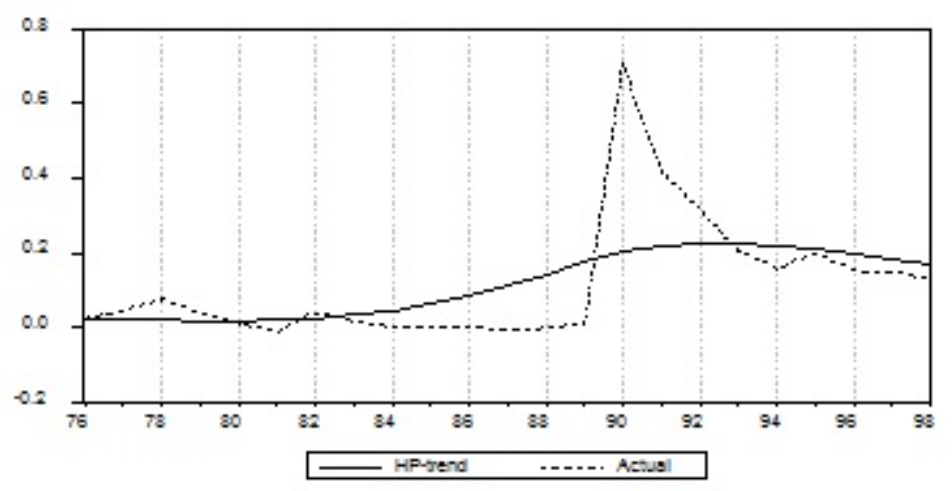

Figure A.1. Current transfers balance as a share of GDP

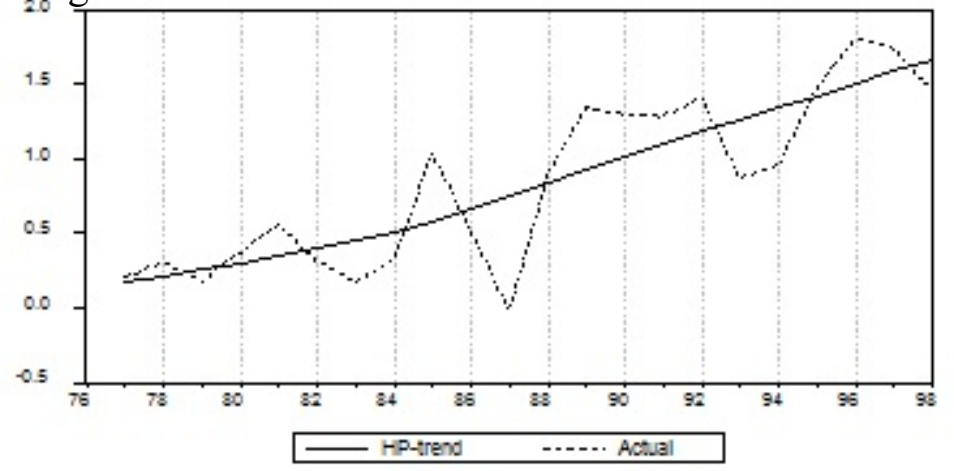

Figure A.2. Direct investment balance as a share of GDP

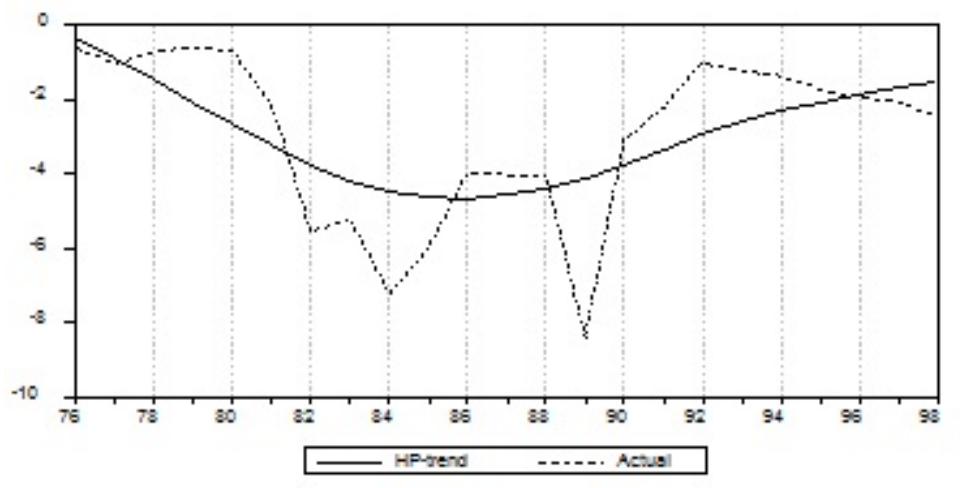

Figure A.3. Income balance as a share of GDP 


\section{REFERENCES}

Bouzas, R. (2001) "El MERCOSUR diez años después. ¿Proceso de aprendizaje o déjà vu?" (MERCOSUR Ten Years Later: Learning Process or déjà vu?) Desarrollo Económico, 41: 1792000. Also (2002) in J. Tulchin, R. Espach and H. Golding (eds.) Paths to Regional Integration: The Case of MERCOSUR. Washington, DC: Woodrow Wilson Center.

Calvo, G., L. Leiderman and C. Reinhart (1993) "Capital Inflows and Real Exchange Rate Appreciation in Latin America”. IMF Staff Papers, 40: 108-51.

Cavallo, D. and G. Mondino (1995) “Argentina's Miracle? From Hyperinflation to Sustained Growth". In M. Bruno and B. Pleskovic (eds.) Annual World Bank Conference on Development Economics. Washington, DC: World Bank.

CEPAL (1986) Estadísticas económicas internacionales de corto plazo de la Argentina: Sector externo y condiciones económicas internacionales (Argentina's Short Term International Economic Statistics: External Sector and International Economic Conditions), Vol. I. Buenos Aires: Economic Commission for Latin America and the Caribbean.

Corden, W. M. (1987) "Protection and Liberalization: A Review of Analytical Issues". IMF Occasional Paper No. 54. Washington, DC: International Monetary Fund.

Corden, W. M. (1990) "Exchange Rate Policy in Developing Countries". World Bank WPS412. Washington, DC: World Bank.

Corden, W. M. (1993) "Exchange Rate Policies for Developing Countries". Economic Journal, 103: 198-207.

Díaz Alejandro, C. (1965) Exchange Rate Devaluation in a Semi-industrialized Country: The Experience of Argentina, 1955-61. Cambridge (Mass.): MIT Press.

Edwards, S. (1984) "The Order of Liberalization of the External Sector in Developing Countries". Princeton Essays in International Finance No. 156. Princeton: Princeton University.

Edwards, S. (1991) Comments to "Chile's Experience with Stabilization Revisited" by V. Corbo and A. Solimano. In M. Bruno, S. Fischer, E. Helpman and N. Liviatan eds. Lessons of Economic Stabilization and its Aftermath: Inflation and Stabilization. Cambridge (Mass.): MIT Press.

Edwards, S. and M. Savastano (1999) "Exchange Rates in Emerging Economies: What Do We Know? What Do We Need to Know?”. NBER Working Paper 7228. Washington, DC: National Bureau of Economic Research.

Harberger, A. (1985) “Crisis fiscal e internacional de Panamá: ¿un problema o dos?” (Panama’s 
Fiscal and International Crisis: One Problem or Two?). Panama: Ministerio de Planificación y Política Económica.

Harberger, A. (1986) "Economic Adjustment and the Real Exchange Rate". In S. Edwards and L. Ahamed (eds) Economic Adjustment and Exchange Rates in Developing Countries. Chicago and London: University of Chicago Press.

Hjertholm, P. (1999) "Analytical History of Heavily Indebted Poor Country (HIPC) Debt Sustainability Targets". Discussion Paper 00-03, Institute of Economics. Copenhagen: University of Copenhagen.

IMF (1993) Balance of Payments Manual. Washington, DC: International Monetary Fund.

Jarvis, L. (1974) "Cattle as Capital Goods and Ranchers as Portfolio Managers: An Application to the Argentine Cattle Sector". Journal of Political Economy, 82: 489-520.

Kosacoff, B. (1993) "La industria argentina: un proceso de reestructuración desarticulada" (Argentina's Industry: A Disarticulated Restructuring Process). In B. Kosacoff et al. El desafio de la competitividad (The Challenge of Competitiveness). Buenos Aires: CEPAL/Alianza.

Londero (1997) "Trade Liberalization with a Fixed Exchange Rate". International Trade Journal, 11: $247-76$.

Londero, E. (2001) “The Alleged Countercyclical Nature of Argentina's Exports of Manufactures. Journal of International Trade and Economic Development, 10: 151-73.

Londero, E., J. Remes and S. Teitel (1998) "Argentina: Natural Resources and Industrial Policy". In E. Londero, S. Teitel et al. (1998) Resources, Industrialization and Exports in Latin America. London and New York: Macmillan and St. Martin's.

Perron, P. (1990) "Testing for a Unit Root in a Time Series with a Changing Mean". Journal of Business and Economic Statistics, 8: 153-62.

Salter, W.E.G. (1959) "Internal and External Balance: The Role of Price and Expenditure Effects". Economic Record, 35: 226-38.

Swan, T.W. (1955) “Longer-Run Problems of the Balance of Payments". In R. Caves and H. Johnson (eds.) (1968) Readings in International Economics, Irwin: Homewood.

World Bank (1989) Argentina: Reforms for Price Stability and Growth. Report No. 7994-AR, Volume II. Washington DC: World Bank.

World Bank (2000) Global Development Finance. Washington DC: World Bank. 